Nat. Hazards Earth Syst. Sci., 20, 933-946, 2020

https://doi.org/10.5194/nhess-20-933-2020

(C) Author(s) 2020. This work is distributed under the Creative Commons Attribution 4.0 License.

\title{
Run-up, inundation, and sediment characteristics of the 22 December 2018 Sunda Strait tsunami, Indonesia
}

\author{
Wahyu Widiyanto $^{1,2}$, Shih-Chun Hsiao ${ }^{1}$, Wei-Bo Chen ${ }^{3}$, Purwanto B. Santoso ${ }^{2}$, Rudy T. Imananta ${ }^{4}$, and \\ Wei-Cheng Lian ${ }^{1}$ \\ ${ }^{1}$ Department of Hydraulic and Ocean Engineering, National Cheng Kung University, Tainan, 701, Taiwan \\ ${ }^{2}$ Department of Civil Engineering, Universitas Jenderal Soedirman, Purwokerto, 53122, Indonesia \\ ${ }^{3}$ National Science and Technology Center for Disaster Reduction, New Taipei City, 23143, Taiwan \\ ${ }^{4}$ Meteorological, Climatological, and Geophysical Agency (BMKG), Jakarta, 10720, Indonesia
}

Correspondence: Shih-Chun Hsiao (schsiao@mail.ncku.edu.tw)

Received: 1 October 2019 - Discussion started: 16 October 2019

Revised: 22 January 2020 - Accepted: 2 March 2020 - Published: 6 April 2020

\begin{abstract}
A tsunami caused by a flank collapse of the southwest part of the Anak Krakatau volcano occurred on 22 December 2018. The tsunami affected the coastal areas located at the edge of the Sunda Strait, Indonesia. To gain an understanding of the tsunami event, field surveys were conducted a month after the incident. The surveys included measurements of run-up height, inundation distance, tsunami direction, and sediment characteristics at 20 selected sites. The survey results revealed that the run-up height reached $9.2 \mathrm{~m}$ in Tanjungjaya and an inundation distance of $286.8 \mathrm{~m}$ was found at Cagar Alam, part of Ujung Kulon National Park. The tsunami propagated radially from Anak Krakatau and reached the coastal zone with a direction between 25 and $350^{\circ}$ from the north. Sediment samples were collected at 27 points in tsunami deposits with a sediment thickness of $1.5-12.7 \mathrm{~cm}$. The average distance from the coast of the area with significant sediment deposits and the deposit limit are $45 \%$ and $73 \%$ of the inundation distance, respectively. Sand sheets were sporadic, highly variable, and highly influenced by topography. Grain sizes in the deposit area were finer than those at their sources. The sizes ranged from fine sand to boulders, with medium sand and coarse sand being dominant. All sediment samples had a well-sorted distribution. An assessment of the boulder movements indicates that the tsunami run-up had minimum velocities of $4.0-4.5 \mathrm{~m} \mathrm{~s}^{-1}$.
\end{abstract}

\section{Introduction}

A tsunami took place in the Sunda Strait on 22 December 2018, at 22:00 western Indonesia time (UTC+7). It shocked the local residents because it came without any warning signs, such as earthquake shocks. The source of the tsunami was the Anak Krakatau volcano, a sea mountain in the middle of the Sunda Strait. The southwestern slope of the mountain experienced a landslide that resulted in the movement of seawater, which propagated to land in the form of a tsunami wave. When the tsunami reached land, its large energy caused a lot of damage and casualties. Records obtained from the Indonesian National Disaster Management Authority (Indonesian - Badan Nasional Penanggulangan Bencana; BNPB) show 430 deaths, 1015 collapsed houses, and a lot of other damage (e.g., to seawalls, revetments, jetties, boats, and cars). The affected areas in Banten Province include the Pandeglang and Serang districts, and those in Lampung Province include the regencies of South Lampung, Tanggamus, and Pesawaran.

The Sunda Strait is home to the Krakatau (or Krakatoa) volcano. It is famous for the 1883 Krakatau eruption, which caused a $30 \mathrm{~m}$ tsunami that led to 36000 fatalities and affected Earth's climate and weather for several weeks, as reported by Verbeek (1884). The 1883 eruption of Krakatau and the resulting tsunami have been widely discussed (e.g., Yokoyama, 1987; Camus et al., 1992; Maeno and Imamura, 2011; Paris et al., 2014). A young volcano called Anak Krakatau (Child of Krakatau) appeared above sea level in 1929. It grew to $338 \mathrm{~m}$ a.s.l. (above sea level) in Septem- 
ber 2018. This very active volcano was the source of the tsunami discussed in the present study.

The generation of the tsunami that occurred on 22 December 2018 in the Sunda Strait was triggered by the collapse of a flank in the southwest part of the Anak Krakatau volcano. Satellite imagery shows that the area of the body of the marine volcano that was lost was 64 ha; the collapsed volume was estimated to be $150000000-180000000 \mathrm{~m}^{3}$ (Kasbani, 2019). As a result of the collapse of some of the volcano's body, the volcano's height decreased from 338 to $110 \mathrm{~m}$ a.s.l. The tsunami caused by the collapse of the Anak Krakatau flank was investigated by Giachetti et al. (2012). They used a numerical model to simulate an unstable-flank collapse in the southwest part of Anak Krakatau. A hypothetical volume of $280000000 \mathrm{~m}^{3}$ produces a wave with an initial height of $43 \mathrm{~m}$ on the Sertung, Panjang, and Rakata islands that then spreads to the beaches on the western part of Java, including Merak, Anyer, Carita, Panimbang, and Labuhan, and Sumatra, reaching the city of Bandar Lampung. The actual area affected by the 22 December event is consistent with their model but different in magnitude due to the use of the worstcase scenario in the simulation. The numerical modeling of the December 2018 Anak Krakatau tsunami was performed by Heidarzadeh et al. (2020), while Muhari et al. (2019) conducted field surveys of this event to record tsunami run-up along the coasts of the Sunda Strait.

Tsunamis in the Sunda Strait are of great concern because the strait is important both locally and globally. It connects the two main islands of Java and Sumatra, whose populations account for $79 \%$ of Indonesia's population (BPS - Statistics Indonesia, 2019). About 6.9 million people live in the coastal area of the strait in Banten Province and Lampung Province (BPS - Statistics of Banten Province, 2019; BPS - Statistics of Lampung Province, 2019). The strait, between Merak and Bakauheni, is the busiest interisland crossing in Indonesia, with 17824392 passengers and 4218548 vehicles in 2018 (Dirjen Perhubungan Darat, 2019). The strait is also an international route for large ships. It is the second-most crowded waterway after the Strait of Malacca, with 70000 vessels a year passing it (Soeriaatmadja, 2019). There are three industrial regions at the edge of the strait, namely Cilegon, Serang, and Tanggamus. There is also a special economic zone in this region, namely Tanjung Lesung. The beaches in the strait are a tourist destination. There are two UNESCO world heritage sites across from each other: one on the western tip of Java (Ujung Kulon National Park) and the other on the southern tip of Sumatra (Bukit Barisan Selatan National Park). Bandar Lampung, which has a population of 1 million, is the provincial capital and faces the strait directly. Jakarta, the capital of the Republic of Indonesia, is relatively close to the strait.

Post-tsunami field surveys were conducted to obtain data for future mitigation and development activities in the region. The surveys began exactly a month after the tsunami, 22 January, and ended on 28 January 2019. Our team included people from Indonesia and Taiwan. We carried out measurements of the run-up height and inundation distance of the tsunami. In addition, we also identified flow directions and sediment deposits caused by the tsunami.

\section{Study area}

The tsunami has had a serious impact on life in the surrounding area. The affected area covers the coastal area on the western tip of Java (Banten Province) and the southern tip of Sumatra (Lampung Province). Banten Province covers two districts, namely Serang and Pandeglang. Lampung Province covers South Lampung Regency and the provincial capital of Lampung, namely Bandar Lampung. Post-tsunami field surveys were conducted in these areas. We selected 20 sites for observation and measurement (Table 1 and Fig. 1). These sites are located along $140 \mathrm{~km}$ of coast on Java and $80 \mathrm{~km}$ of coast on Sumatra. Sites 13 and 14 were reached by boat because of the difficult land route.

Land use at these sites includes housing, agriculture, tourism, and a national park. Sites 1, 2, 4, 7, 8, 9, and 10 (Karangsuraga, Pasauran, Pejamben, Tanjungjaya 1, and Tanjung Lesung 1-3) have houses mixed with hotels, resorts, and villas. Sites 13, 15, 17, and 20 (Kertajaya Sumur, Bumi Waras, Wayurang 2, and Kunjir) have high-density housing. Sites 3, 6, 7, and 16 (Sukarame, Mekarsari, Tanjungjaya 1, and Wayurang 1) have agricultural land. Site 14 is a protected national park with limited access. Although this site has no residents, it is very important to review it because it includes the only Javan rhino (Rhinoceros sondaicus) habitat in the world. The Javan rhino is one of the most threatened mammals on Earth, with a population of less than 100. The distribution of the rhino indicates that tsunamis are a significant risk to the species in the area (Setiawan et al., 2018). Each site has a different beach profile. Most sites are natural beaches. Sites 2, 4, 8, 9, and 10 (Pasauran, Pejamben, and Tanjung Lesung 1-3) have coastal structures (e.g., seawalls), and sites 5, 17, and 20 (Sukamaju, Wayurang 2, and Kunjir) have revetments.

\section{Method}

Measurements of run-up and inundation were conducted using conservative terrestrial surveying methods with optical and laser devices (e.g., total stations, handheld GPS devices, and laser distance meters). We measured run-up and inundation based on the coastline at the time of the surveys. Run-up was corrected to calculate heights above sea level because the tide level at the time of the actual tsunami was different from the tidal level at the time of the surveys. We use WXTide software version 4.7 for correcting elevation. Elevation values of each survey site were corrected with the nearest tidal gauge available. We used three stations in Ciwandan, Labuhan, and Teluk Betung for corrections. The maximum run-up and inundation limits are based on remaining tsunami 


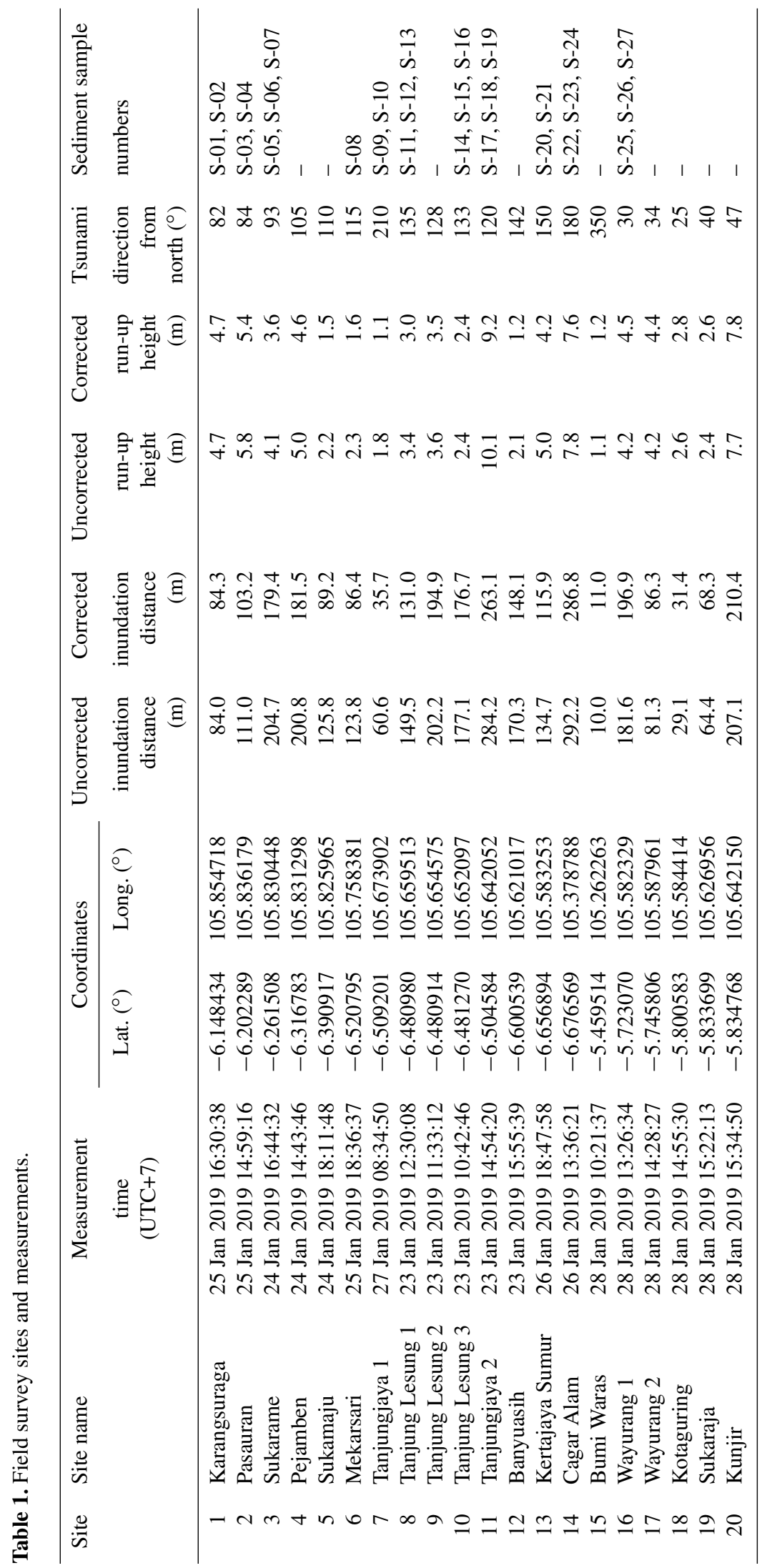




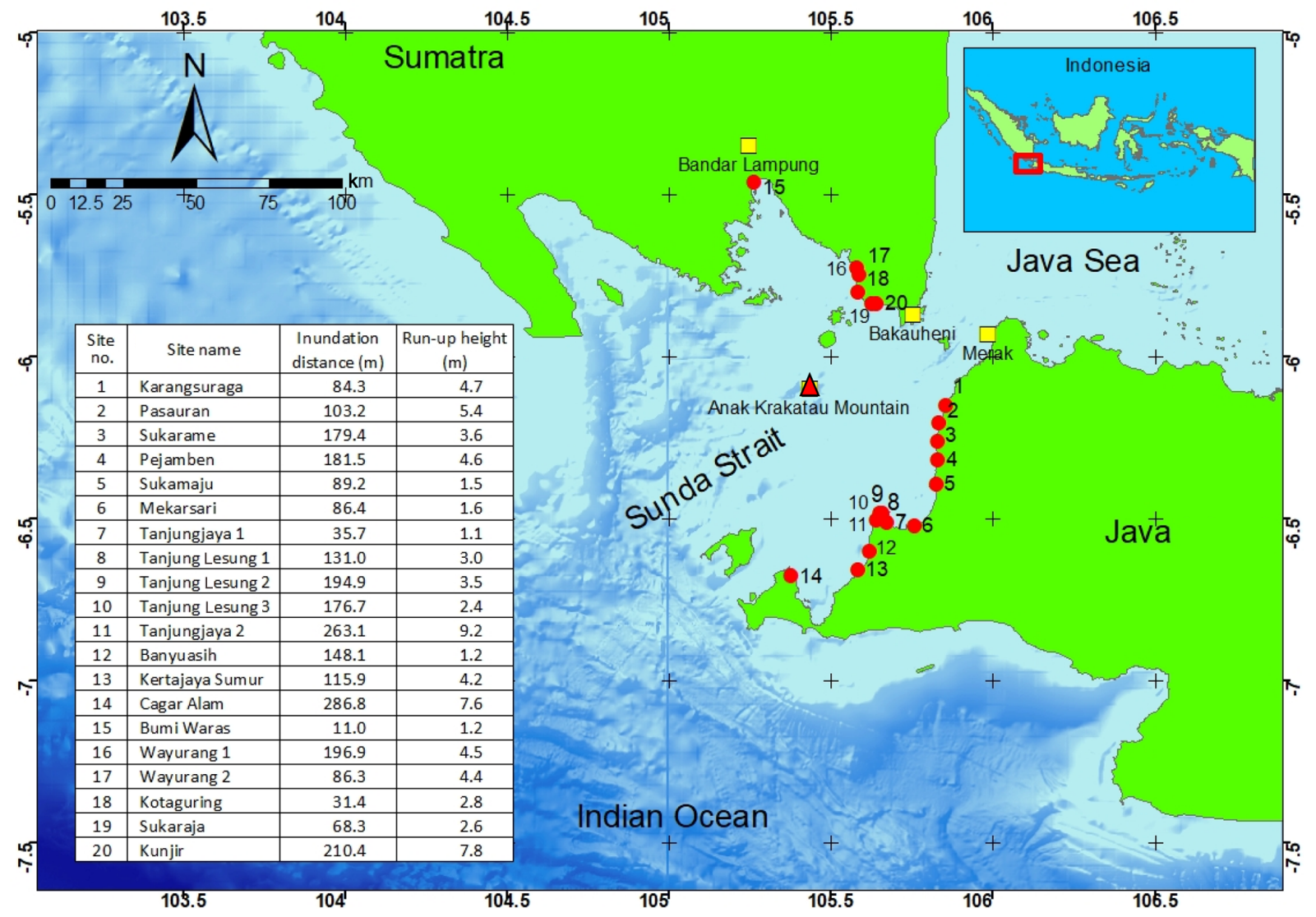

Figure 1. Locations of field surveys. The Sunda Strait lies between Java and Sumatra in Indonesia. Red dots and associated numbers show survey site locations and survey site numbers, respectively. Inundation distances and run-up heights for each site are shown in the table. Map layers are from the Geospatial Information Agency, Indonesia (@ BIG, 2020).

trail marks at measurement locations. The tracks were in the form of debris, fallen trees, plants that had changed color, and damage to buildings. The observed damage to buildings and structures was caused by the tsunami because there were no other causes, such as the earthquake sand liquefaction in the 2018 Sulawesi tsunami (Widiyanto et al., 2019). In addition, information regarding inundation limits and the highest run-up was also obtained from eyewitnesses. IOC Manuals and Guides No. 37 (1998 and 2014) and field survey reports (Maramai and Tinti, 1997; Farreras, 2000; Matsutomi et al., 2001; Fritz and Okal, 2008) were used as guidelines for the implementation of this field survey.

Sediment samples were collected from selected points at measurement locations that could be in the swash zone, nearshore, on berms, or in deposit areas (Table 2 and Fig. 2). The measurement of deposit thickness in sandy sheets was carried out by digging a number of shallow holes. The measured thickness was considered to be near the maximum thickness. This method was qualitative and subjective because tsunami deposits are discontinuous, sporadic, and scattered over a flooded area. Sand sheets deposited on land vary greatly due to the influence of sedimentary sources and to- pography. A pit was made at each selected point to observe layers suspected to have been produced by the tsunami. We took only one sample at each pit for laboratory testing and did not take vertical samples at intervals of $1 \mathrm{~cm}$, as done by some researchers (Gelfenbaum and Jaffe, 2003; Hawkes et al., 2007; Srinivasalu et al., 2007; Srisutam and Wagner, 2010), because a detailed analysis was not our focus, particularly not the number of tsunami waves and the vertical variation in sediment. The grain size of the samples obtained from the field was tested using ASTM standard sieve analysis. In addition, we investigated boulder movement at four sites.

\section{Run-up}

The run-up was measured by determining the height difference between the highest point of seawater rise onto land and the coastline. Run-up is influenced by the characteristics of the ground surface and slope. The measurement results from our field surveys show that run-up ranged from 1 to $9 \mathrm{~m}$ (Table 1 and Fig. 1). The values in the table and figure have been corrected for tide to obtain elevation from sea level at the 

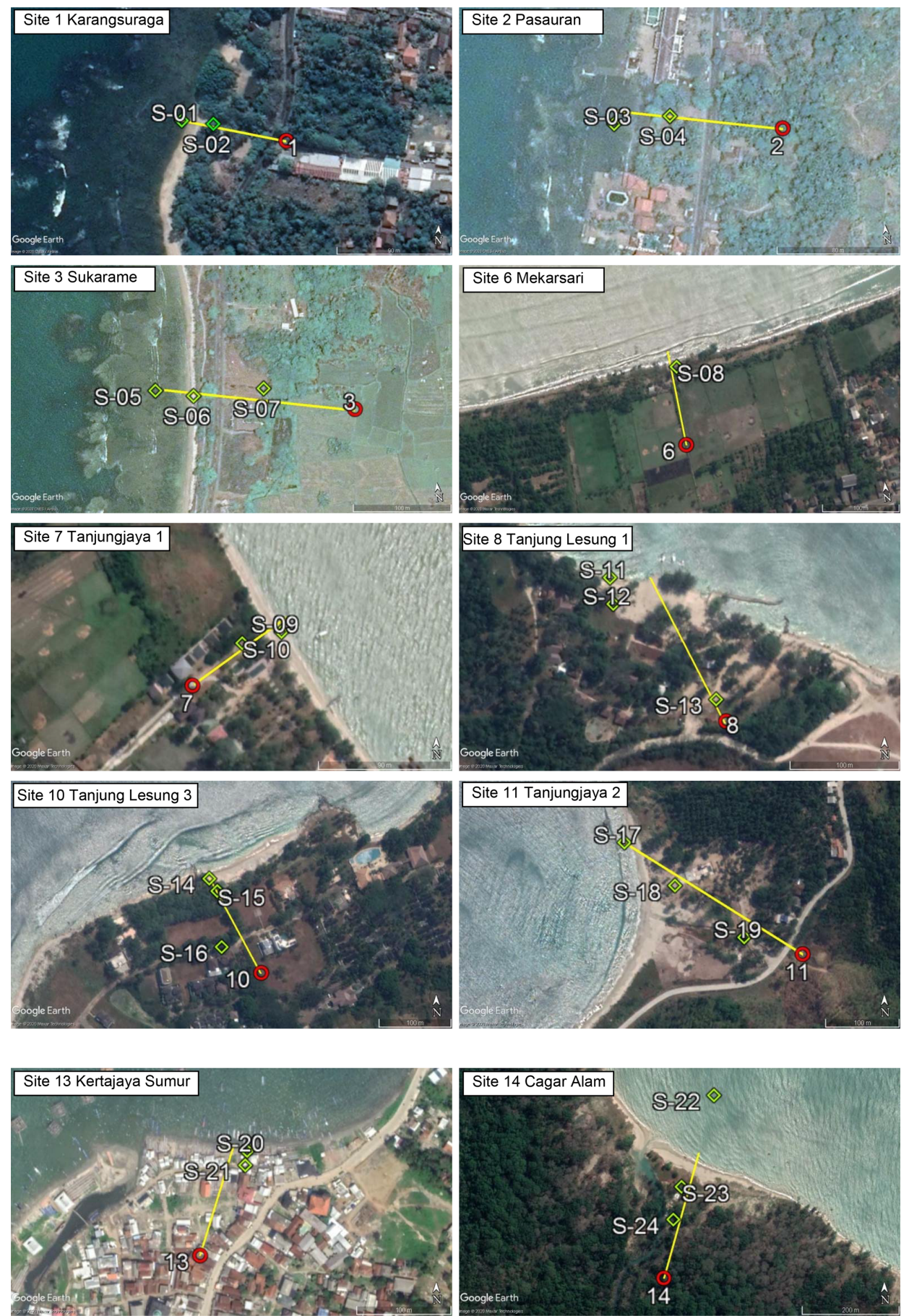

Figure 2. Aerial photographs from (C) Google Earth of transects including highest run-up point and deposit pit. 


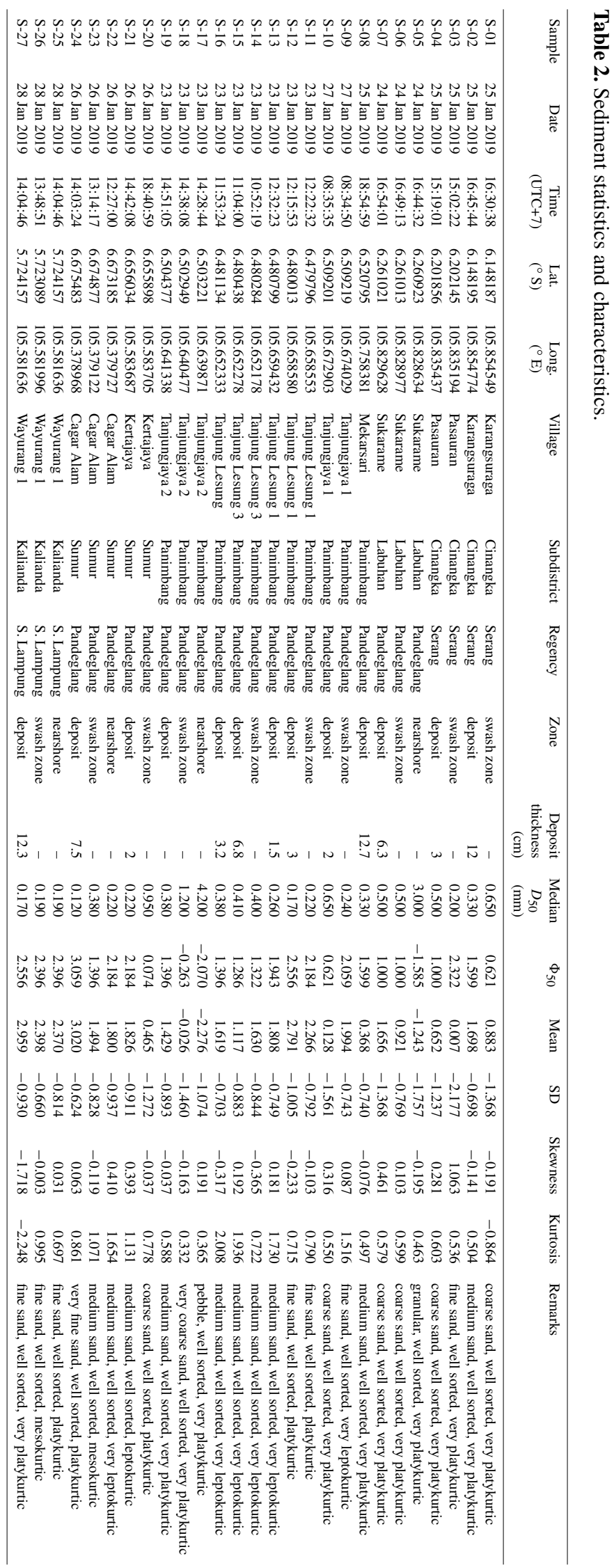

time of the tsunami. A run-up height of about $1 \mathrm{~m}$ was found in many locations at which no damage was found. The highest run-up was found at the Tanjungjaya 2, Cagar Alam, and Kunjir sites, with heights of 9.2, 7.6, and $7.8 \mathrm{~m}$, respectively. Site Tanjungjaya 2 is located at Cipenyu Beach. Muhari et al. (2019) reported a maximum run-up height of $13 \mathrm{~m}$ in the area around Tanjungjaya-Cipenyu Beach. This value is significantly different from our maximum run-up since we measure in a flat-valley part of Cipenyu Beach, while Muhari et al. (2019) measured on the hilly coast of the beach area. The Tanjungjaya 2 site is a private resort with many tourists. The topography is relatively flat but suddenly rises at a distance of about $250 \mathrm{~m}$ from the coastline due to a long hill. A large boulder moved by the tsunami was found at this site. The $\mathrm{Ca}$ gar Alam (sanctuary) site is part of the Ujung Kulon National Park. This site has a flat topography and a dense forest. The guard post and water police office were completely destroyed by the tsunami. The Kunjir site, which is densely inhabited, had the second-highest number of victims after the Sumur site. This site is located on Sumatra about $38 \mathrm{~km}$ from the tsunami source.

Our surveyed run-up heights are compared with the published tide gauge records of Heidarzadeh et al. (2020). Three tide gauges mentioned in the article (Ciwandan, Marina Jambu, and Panjang) are used. Maximum amplitudes at Ciwandan, Marina Jambu, and Panjang are 1.15, 2.8 , and $1.25 \mathrm{~m}$, respectively. The Ciwandan tide gauge is used to evaluate run-up heights at sites Karangsuraga, Pasauran, Sukarame, and Pejamben. The Marina Jambu tide gauge is used to evaluate run-up heights at sites Sukamaju, Karangsari, Tanjungjaya 1, Tanjung Lesung 1-3, Tanjungjaya 2, Banyuasih, Kertajaya Sumur, and Cagar Alam. Additionally, the Panjang tide gauge is used to evaluate the sites of Bumi Waras, Wayurang 1, Wayurang 2, Kotaguring, Sukaraja, and Kunjir. It is indicated that averaged run-up heights of each site associated with the tide gauge are $4,1.15$, and 3.1 times larger than the maximum amplitude at Ciwandan, Marina Jambu, and Panjang, respectively. The sites are relatively far from the tide gauge.

\section{Inundation}

The distance from the run-up point to the coastline is defined as the inundation distance (IOC Manuals and Guides No. 37, 2014). This distance can be easily obtained using a distance measurement instrument or GPS. We used a total station for this purpose. The coastline's elevation in our survey was corrected with the tide elevation measured by several tide gauges in the Sunda Strait. The results of our field measurements show that the inundation distance ranged from 10 to $290 \mathrm{~m}$ (Table 1 and Fig. 1). The wave with an inundation distance of $11 \mathrm{~m}$ and a run-up of $1.2 \mathrm{~m}$ at site 15 (Bumi Waras) was not felt by the population. This site was chosen to represent the area of Bandar Lampung, which is the capital of Lampung 
Province. This city has a population of 1 million (2018) and must thus develop tsunami mitigation strategies. The longest inundation distance was found at site $14(286.8 \mathrm{~m})$, in the sanctuary, which also had a high run-up. At this site, measurements were made near the mouth of a small river. Long inundation distances may be caused by relatively flat topography with relatively few obstacles. Tsunamis may also travel faster through a stream channel. A relatively long inundation $(263.1 \mathrm{~m})$ was also found at Tanjungjaya 2, the site with the highest run-up. This site is in the form of a valley plain with a small stream. The slope in the valley is relatively flat and suddenly changes steeply in hilly areas within $250-300 \mathrm{~m}$ of the coastline. The run-up point we recorded is located on the slope change from mild to steep. These mildly sloping and steep areas have slopes of approximately 0.025 and 0.06 , respectively. Local people call this area Cipenyu Beach. This is a sandy beach flanked by cliffs or hilly beaches. Fortunately, not many people live around this site other than at a resort complex, which suffered severe damage.

\section{Tsunami wave direction}

The tsunami spread out from its source on the Anak Krakatau volcano to the beaches at the edge of the Sunda Strait. To determine the direction of the tsunami that arrived at the beach, we obtained information from eyewitnesses. The tsunami hit at night, and thus its arrival was difficult to see. Fortunately, it hit during a full-moon period, so there was some light. In addition to eyewitness accounts, we obtained evidence in the field related to the direction of the tsunami propagation. The evidence was in the form of fallen tree trunks, sloping vegetation and shrubs, damaged buildings, and building components carried away by the flow (Fig. 3).

Our survey results show that the direction of the tsunami propagation was radial from the source (Fig. 4). The tsunami traveled east along the coast between Anyer and Labuhan (sites 1-6). In the vicinity of Tanjung Lesung (sites 7-13), the tsunami was directed to the southeast, and in part of Ujung Kulon National Park (Site 14), the tsunami was directed southward. The tsunami was directed to the north and slightly to the northeast on Sumatra (sites 15-19). The westward tsunami toward the Tanggamus area was relatively small and insignificant. We did not include this area in the survey. The smaller magnitude of the tsunami to the west is likely due to obstruction by the island of Sertung and bathymetry factors. The Anak Krakatau mountain avalanche had a southwest direction, but the tsunami in this direction had no impact on human life because it leads to the open sea (the Indian Ocean), with increasing depth from the tsunami source. The precise tsunami wave direction from the north as it arrived in the coastal area is given in Table 1 for the field survey sites. The direction ranges from 25 to $350^{\circ}$ from the north, indicating radial propagation of the tsunami wave.

\section{Sediment characteristics}

\subsection{Tsunami deposits}

Prehistoric (paleo)tsunamis have been identified from sediment deposits in several studies (Atwater, 1992; Dawson and Shi, 2000; Peters et al., 2007). Sediment deposits can be used to explain and reconstruct significant tsunami events (Dawson et al., 1995; Van Den Bergh et al., 2003). The present study attempts to describe the impact of a recent tsunami on sediment movement around the coastal area. The tsunami carried sediment from the coast inland. However, not all sites that we measured had significant sediment deposits. Only places with a sufficient source of material had clearly observable sediment deposits (Fig. 5). The survey sites used for sediment samples are shown in Fig. 2. Sediment deposits generally do not spread evenly and continuously but are separated at certain locations, which allow the deposits to settle. Topography controls sediment deposits; for instance, there are more sediment deposits at ground surface depressions.

The best location for the observation of tsunami sediment is about $50-200 \mathrm{~m}$ inland from the coastline (Srisutam and Wagner, 2010) or about 50-400 m inland (Moore et al., 2006), a range used for the 2004 Sumatra-Andaman tsunami. In this present study, the 12 deposit pits were 9-195 m from the shoreline. Four deposit pits were less than $50 \mathrm{~m}$ from the shoreline (Fig. 6). Three of them were at sites 1, 2, and 7, respectively, due to the short inundation and beach scarp. Another was at site 13 (Kertajaya Sumur), where high-density housing blocked the sediment transport and created a deposit at a short distance from the shoreline.

The interpretation of tsunami magnitude, especially runup and inundation based on tsunami deposits, is challenging (Dawson and Shi, 2000). However, the relationship between deposits and run-up or inundation is still not convincing because of the high variability in tsunami deposits in terms of thickness and location. Soulsby et al. (2007) proposed a mathematical model for reconstructing tsunami runup from sedimentary characteristics. The run-up distance for sediment is related to the run-up distance for water as

$$
R_{\mathrm{S}}=\frac{R_{\mathrm{W}}}{1+\alpha \gamma},
$$

where $R_{\mathrm{S}}$ is the maximum distance inland for sediment deposition, $R_{\mathrm{w}}$ is the run-up limit for water, $\alpha$ is as shown in Eq. (2), and $\gamma$ is a comparison factor between uprush time and total uprush-plus-backwash time.

$\alpha=\frac{w_{\mathrm{s}} T}{H}$,

where $w_{\mathrm{s}}$ is the settling velocity, $T$ is a period from the time of the first wetting to final drying of inundated ground, and $H$ is the tsunami height. Figure 6 shows the distance of measured sediment deposition and water run-up compared to the distance of theoretical sediment deposition calculated using 

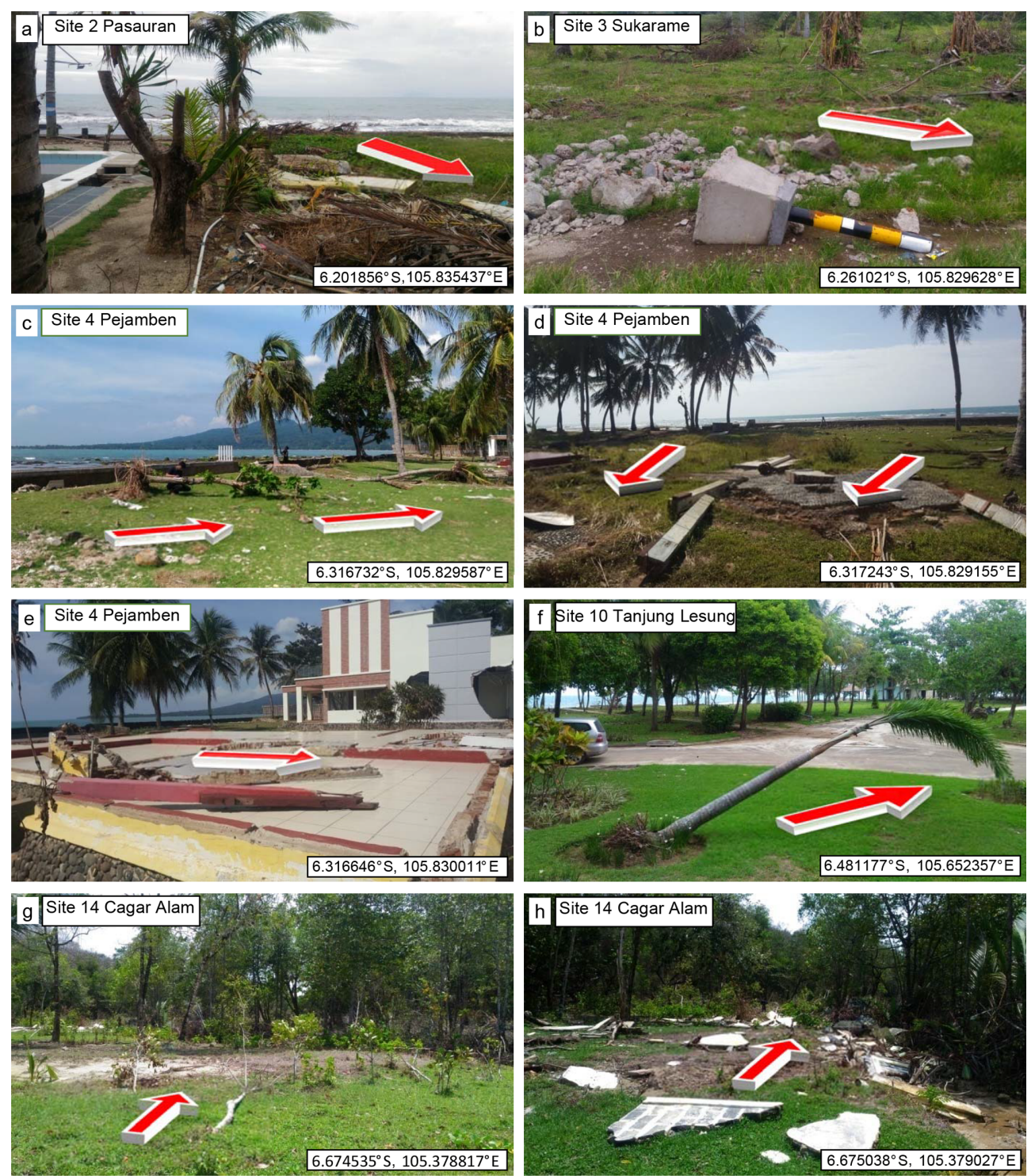

Figure 3. Evidence of tsunami direction. Arrows show the direction of tsunami flow on the ground surfaces.

Eqs. (1) and (2); the results are in good agreement. However, Sukarame, Tanjungjaya 1, and Cagar Alam do not fit well. The three locations have morphological conditions that may not be ideal for applying the theoretical approach. Sukarame has a beach scarp, and the tsunami flows across a stream around $90 \mathrm{~m}$ from the coastline. Tanjungjaya 1 also has a beach scarp, and there is a seawall, although not so high, that may block the sediment movement. Even though Tanjungjaya 1 has abundant material, a low-amplitude tsunami caused little sand transport. Cagar Alam has a relatively larger stream than Sukarame. In addition, Cagar Alam has dense vegetation since it is part of a national park.

As can be seen in Fig. 6, the distance from the coast of the area with significant sediment deposits caused by the tsunami (deposit pit distance) varied in the range of 9-195 m (average
$82 \mathrm{~m}$ ) from the shoreline or $10 \%-70 \%$ (average $45 \%$ ) of the inundation distance. Moreover, the limits where tsunami sediments were found that can still be seen with the naked eye (deposit limit distance) are around 11-244 m (average $122 \mathrm{~m}$ ) from the coastline or $30 \%-90 \%$ (73\% on average) of the inundation distance. Figure 6 also presents the elevation of the deposit pit and deposit limit to the run-up elevation. The average elevation of the deposit pit and deposit limit are $43 \%$ and $72 \%$ of the run-up elevation, respectively.

The sediment samples were tested for gradations in the laboratory. The results for each site are shown in Fig. 8. The sediment in the deposit areas on land is generally finer than at the sources on the beach (nearshore or swash zone). The characteristics of the sediment are discussed in Sect. 7.3. The sediment deposition thickness varied greatly from one point 


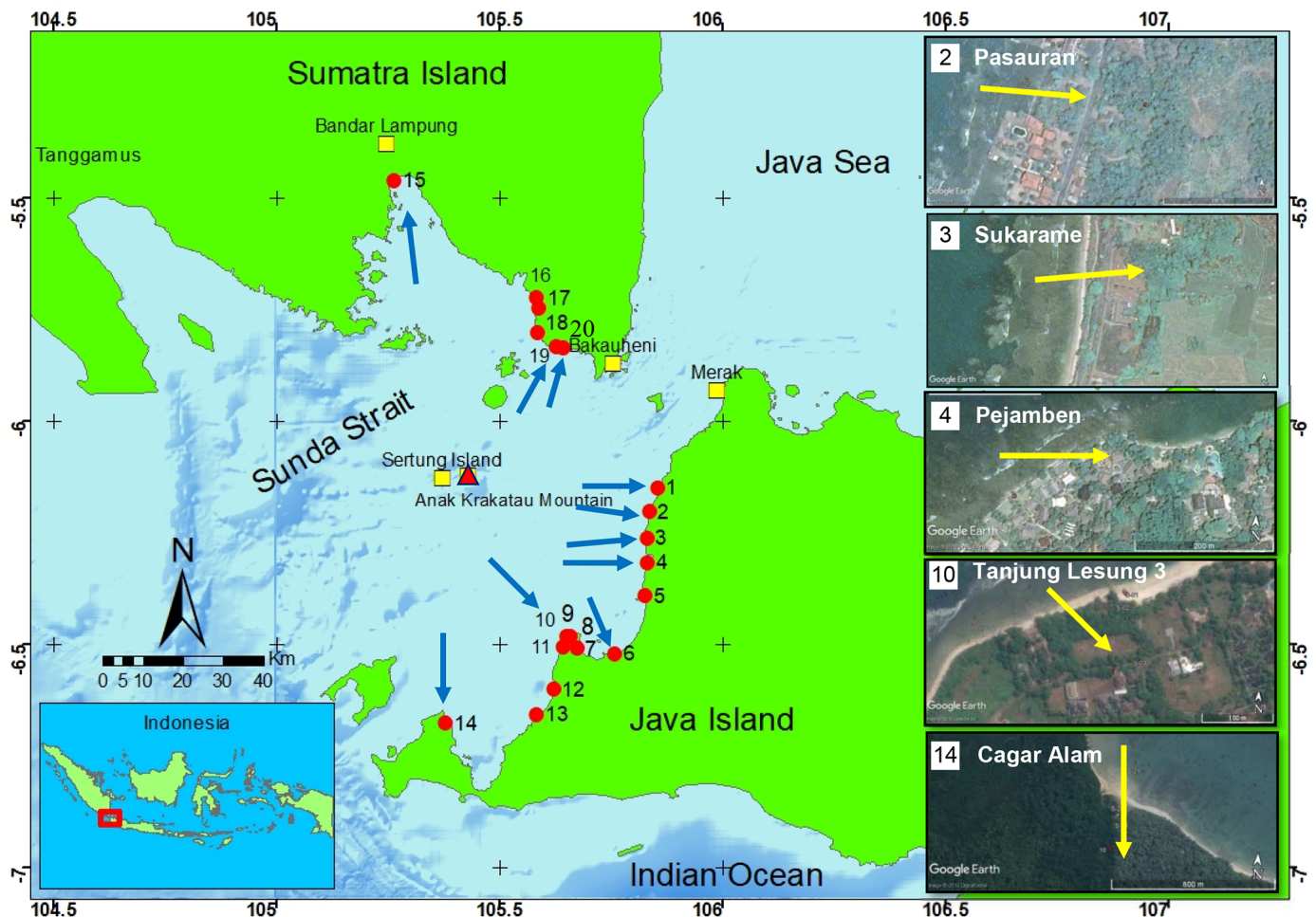

Figure 4. Direction of tsunami propagation; the tsunami spread radially from its source. Numbers next to red dots and in images are survey site numbers. Map layers are from the Geospatial Information Agency, Indonesia (@ BIG, 2020), and images are from @ Google Earth.
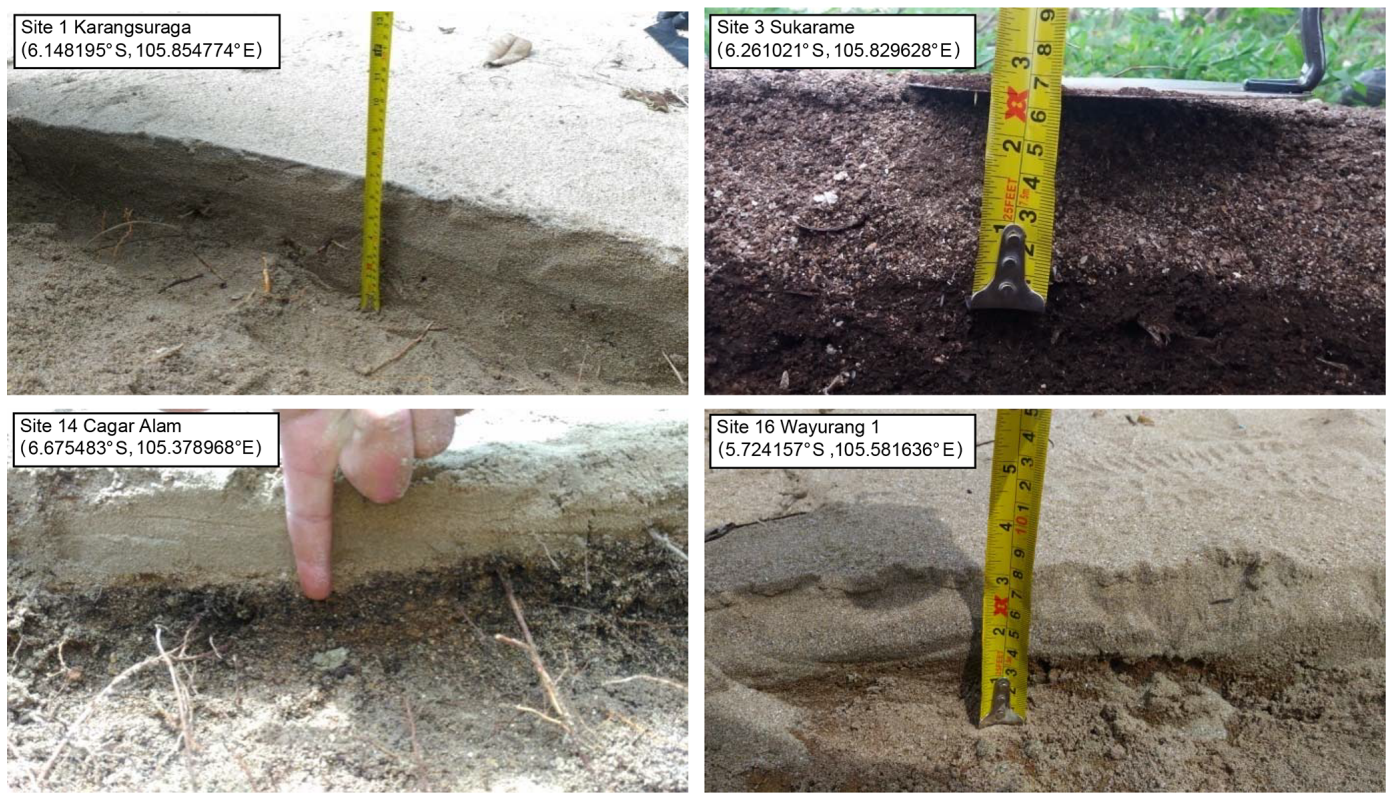

Figure 5. Tsunami sediment deposits; test pits were made to measure the deposit thickness.

to another at the survey sites. We chose a test pit with significant thickness for sampling. The thickness was likely near the maximum sediment thickness in the area.

\subsection{Boulder movement}

Coastal boulder accumulation is usually associated with high-energy events (tsunamis, hurricanes, or powerful storms). A characteristic of many tsunamis is their ability 

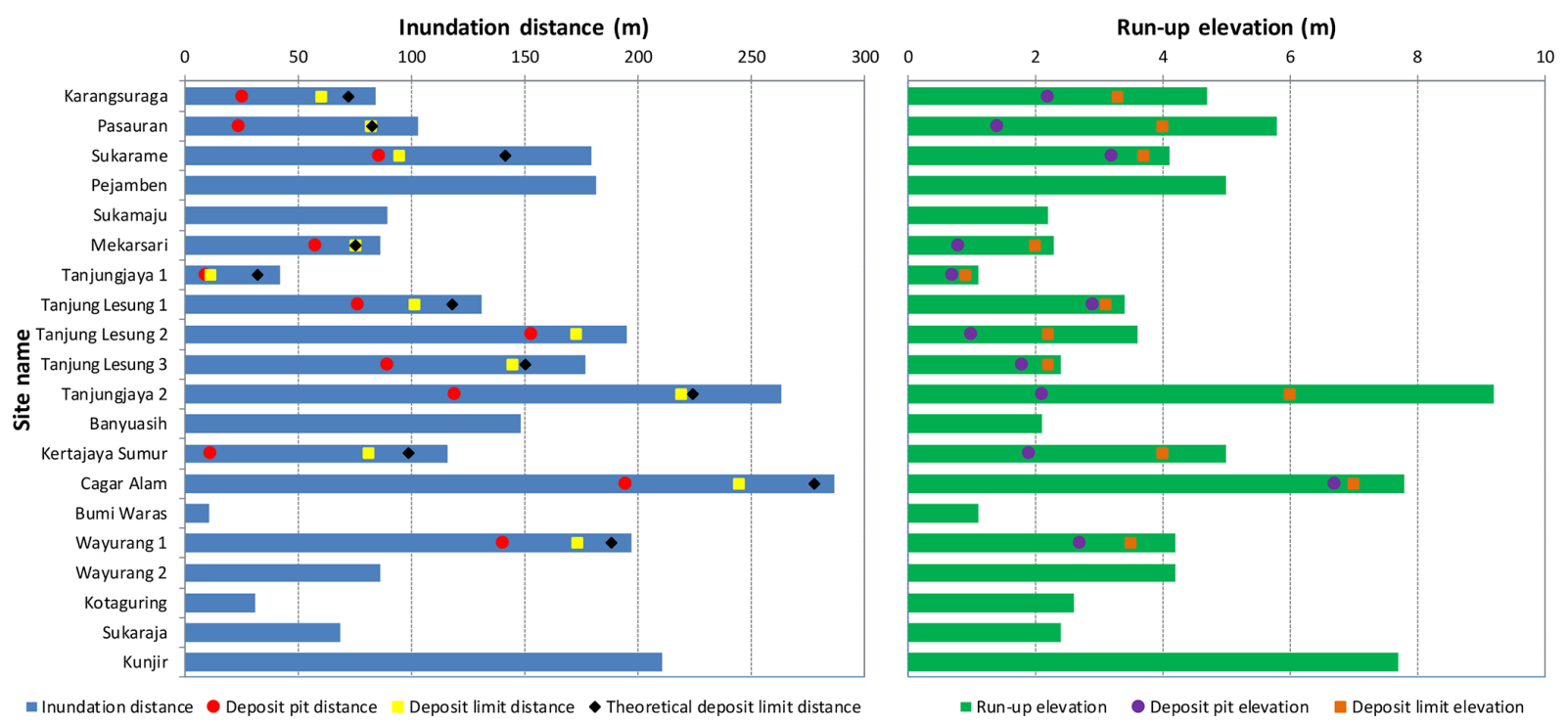

Figure 6. Positions of deposit pits and deposit limit compared to inundation distance and run-up elevation. Theoretical approach for tsunami deposit only available for distance not for elevation.
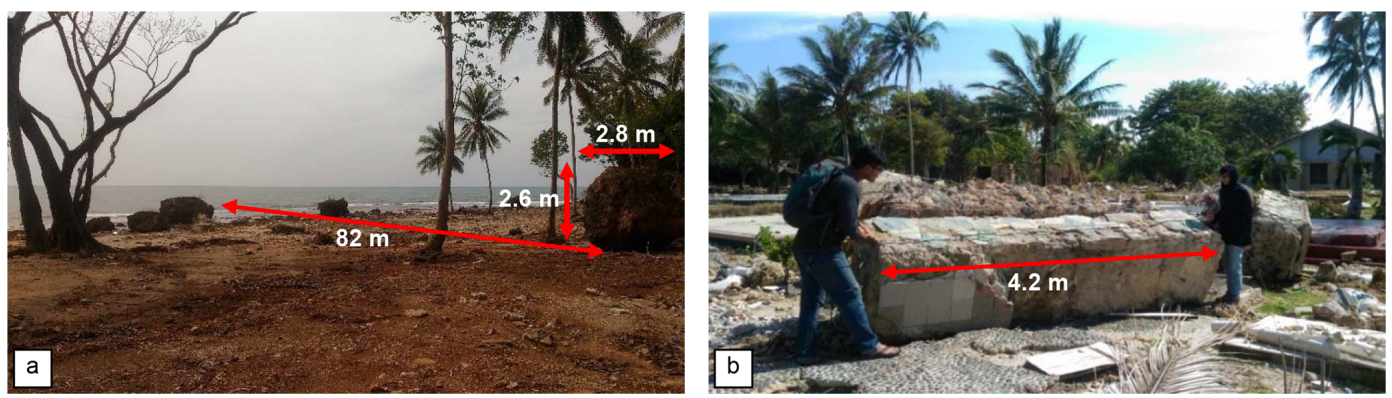

Figure 7. (a) Boulder that moved around $82 \mathrm{~m}$ inland in Tanjungjaya 2 and (b) an element of seawall that moved around $30 \mathrm{~m}$ inland in Pejamben.

to deposit boulders across coastal zones (Dawson and Shi, 2000). Extreme storms also have the ability to deposit boulders (Morton et al., 2007; Richmond et al., 2010). The interpretation of boulders is difficult along coasts where both storms and tsunamis have occurred. We identified boulders moved by a tsunami wave and run-up at three survey sites based on information from eyewitnesses. Eyewitnesses said that these boulders were in new positions after the tsunami. In addition, from the physical criteria given by Morton et al. (2007) and Paris et al. (2010), it was most likely that the boulders were moved by the tsunami. One of the criteria by Morton et al. (2007) that we found in these sites is a relatively thin (average $<25 \mathrm{~cm}$ ) bed composed of normally graded sand consisting of a single structureless bed or a bed with only a few thin layers. Sediment thickness around the boulders was very thin. Paris et al. (2010) reported regarding boulder and fine-sediment transport and deposition by the 2004 Sumatra-Andaman tsunami that most of the sediments deposited on land, from fine sands to coral boul- ders, came from offshore locations, with very high values of shear velocity $\left(>30 \mathrm{~cm} \mathrm{~s}^{-1}\right)$. The boulders we found came from nearshore locations, and most of the boulders were submerged. We estimate that high shear velocities should occur to transport them. These velocities were most likely made possible by the 22 December 2018 Sunda Strait tsunami. At about the time of the tsunami event, a tropical cyclone called Kenanga formed in the Indian Ocean about $1400 \mathrm{~km}$ from the Sunda Strait. Kenanga had a speed of $75 \mathrm{~km} \mathrm{~h}^{-1}$ and was active from 15 to 18 December 2018 (Prabowo, 2019). The influence of this cyclone was weak in the coastal zone, and thus it was unlikely to have moved the boulders.

The largest boulder, measuring $2.7 \mathrm{~m}$ in diameter (10.4 t), was found at site 11 (Tanjungjaya 2), as shown in Fig. 7a. This boulder moved from its original point in the swash zone to $82 \mathrm{~m}$ inland. Other smaller stones were scattered around it. In Tanjung Lesung (sites 8-10), pebbles, cobbles, and small boulders $(25-50 \mathrm{~cm})$ were scattered up to $40 \mathrm{~m}$ from the coastline. At site 4, the seawall built to protect a hotel 

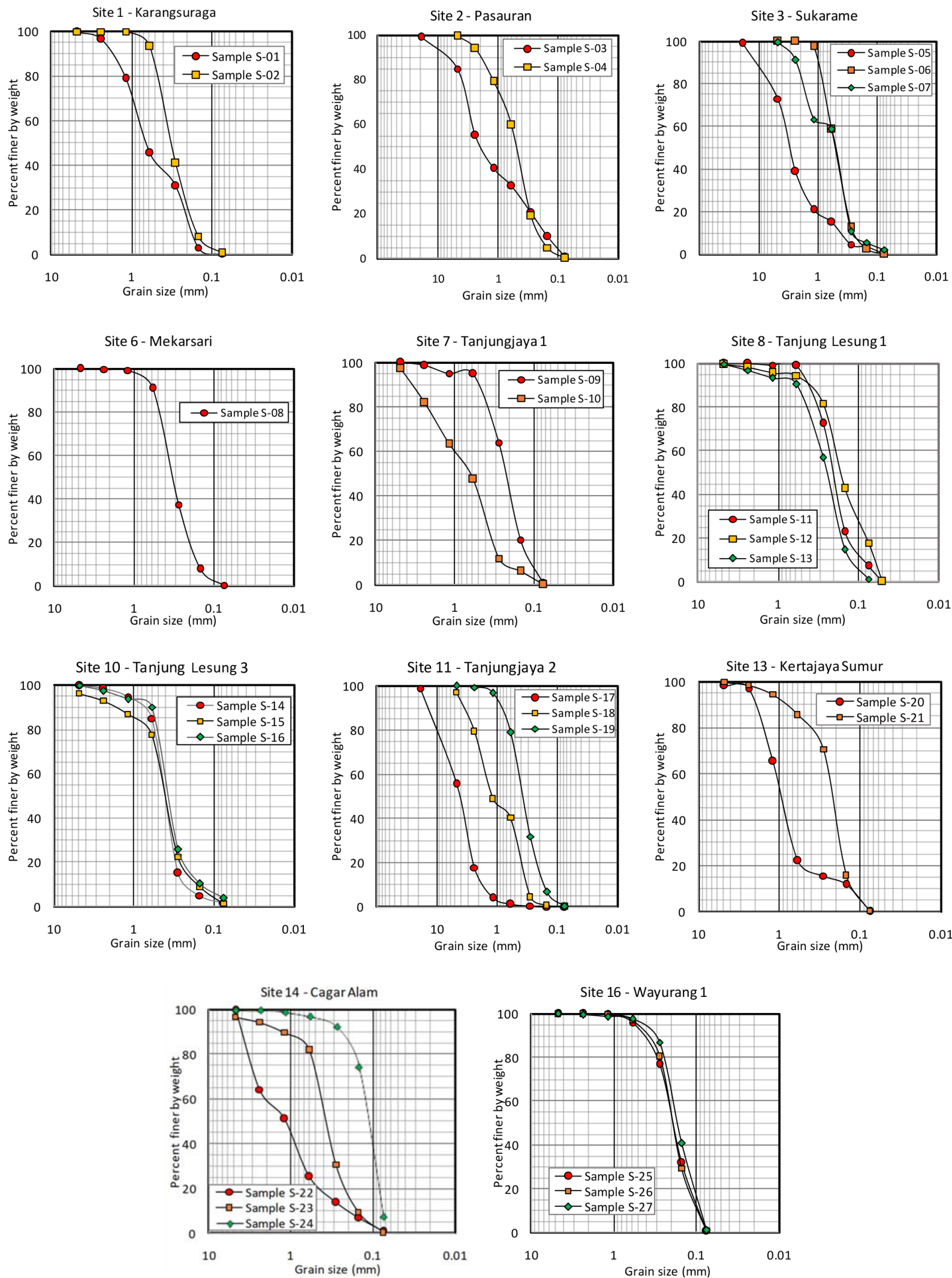

Figure 8. Sediment grain size results from sieve analysis for various sites. 
and villas was partly destroyed and moved ashore. A seawall chunk, measuring $1 \mathrm{~m} \times 1 \mathrm{~m} \times 4.2 \mathrm{~m}(9.5 \mathrm{t})$, made from rubble mound and mortar moved as far as $30 \mathrm{~m}$ from its place of origin (Fig. 7b). Other smaller chunks were also moved.

The characteristics of the boulders moved by a tsunami can be used to estimate the associated flow velocities. For instance, the 2004 Sumatra-Andaman tsunami had flow velocities of $3-13 \mathrm{~m} \mathrm{~s}^{-1}$. This tsunami drove a $7.7 \mathrm{t}$ calcareous boulder $200 \mathrm{~m}$ and an $11 \mathrm{t}$ coral boulder as far as $900 \mathrm{~m}$ (Paris et al., 2010). The velocity was calculated as

$u=\sqrt{\left(\frac{2 \mu m g}{C_{\mathrm{d}} A_{\mathrm{n}} \rho_{\mathrm{w}}}\right)}$,

where $\mu$ is the friction coefficient, $m$ is the boulder mass $(\mathrm{kg})$, $g$ is the gravitational acceleration, $C_{\mathrm{d}}$ is the drag coefficient, $A_{\mathrm{n}}$ is the area of the boulder projected normal to the flow $\left(\mathrm{m}^{2}\right)$, and $\rho_{\mathrm{w}}$ is the density of seawater $\left(\mathrm{kg} \mathrm{m}^{-3}\right)$. The velocities were calculated from Eq. (3) to be $u \geq 4.5 \mathrm{~m} \mathrm{~s}^{-1}$ and $u \geq 4.0 \mathrm{~m} \mathrm{~s}^{-1}$ for the $10.4 \mathrm{t}$ (Fig. 7a) and $9.4 \mathrm{t}$ (Fig. 7b) boulders, respectively.

\subsection{Sand size statistics}

The results of sieve analysis, namely sand grain size distributions, are shown as a cumulative distribution curve of sand grain size. Figure 8 shows the cumulative distribution curve for 12 sites. From the curve, various diameter values were determined, including $d_{95}, d_{84}, d_{50}, d_{16}$, and $d_{5}$. From these diameters, other statistics can be determined, namely the mean, standard deviation, skewness, and kurtosis (Table 2). The mean can be used for grain size classification. The standard deviation is a measure of range that shows the uniformity of a sand sample. A perfectly sorted sample will have sand of the same diameter, whereas poorly sorted sand will have a wide size range. Beach sand size distributions with a standard deviation of $\leq 0.5$ are considered well sorted, and those with a standard deviation of $\geq 1$ are assumed to be poorly sorted. Skewness occurs when the sand size distribution is not symmetrical. A negative skewness value indicates that the distribution tends toward a small $\varphi$ value (large grain size). Kurtosis determines the peakedness of the size distribution. The normal distribution has a kurtosis value of 0.65 . If the distribution is more diffuse and wider than the normal distribution, the kurtosis value will be less than 0.65 (Dean and Dalrymple, 2004).

From our results, the mean values show that medium and coarse were the dominant types of sand in the sample. Very coarse sand, granular sand, and pebbles were found at the Tanjungjaya 2 and Sukarame sites. Fine and very fine sand were also identified at several sites. The range of grain sizes found in the study area depends on the available source material. Wentworth classification was used to assess the grain size. All samples had negative standard deviations, indicating that they had well-sorted distributions.
Of the 10 samples taken from the swash zone, 7 had negative skewness, which indicates a large $\varphi$ value and an erosive tendency in the zone. The numbers of samples with positive and negative skewness were similar (7 and 6 , respectively). Some deposit samples were taken at a distance of less than $50 \mathrm{~m}$ from the coastline, which may still be an erosive environment.

The kurtosis of the tsunami sediment indicates that grain size distributions were flat to peaked. Generally, the major sources of tsunami sediment are swash zones and berm or dune zone sands, where coarse to medium sands are dominant. A minor source of tsunami sediment is the shoreface, where fine to very fine sands are dominant. However, for a coastal area where the shoreface slope is mild, the major source of tsunami sediment is the shoreface. Table 2 provides kurtosis values in which the distribution of sediment ranges from very platykurtic to very leptokurtic.

\section{Conclusion}

We selected 20 sites on Java and Sumatra to observe the impact of the December 2018 Sunda Strait tsunami, which was caused by a mass movement of an Anak Krakatau volcano flank. The survey results revealed that the run-up height ranged from 1 to $9 \mathrm{~m}$, the inundation distance was 10 to $290 \mathrm{~m}$, and the direction of the tsunami was between 25 and $350^{\circ}$. The highest run-up $(9.2 \mathrm{~m})$ was found at site Tanjungjaya 2. The longest inundation distance $(286.8 \mathrm{~m})$ was found at site Cagar Alam which contains a forest area, part of a national park, and a UNESCO heritage site. Sediment samples were taken from 27 points in tsunami deposits with a sediment thickness of $1.5-12 \mathrm{~cm}$. The distance from the coast of the area with significant sediment deposits caused by the tsunami varied in the range of 9-195 $\mathrm{m}$ (average $82 \mathrm{~m}$ ) from the shoreline or $10 \%-70 \%$ (average $45 \%$ ) of the inundation distance. Meanwhile, deposit limit distances were around $11-244 \mathrm{~m}$ (average $122 \mathrm{~m}$ ) or 30\%-90\% (average $73 \%$ ) of the inundation distance. The average elevation of deposit pit and deposit limit are $43 \%$ and $72 \%$ of the run-up elevation, respectively. Sediment material larger than coarse sand (granular sand, pebbles, cobbles, and boulders) was found at several locations. The largest boulder had a diameter of $2.7 \mathrm{~m}$ and a weight of $10.4 \mathrm{t}$. From the boulder movement, the tsunami velocity at the ground surface is estimated to be more than $4.5 \mathrm{~m} \mathrm{~s}^{-1}$. Sand size statistics are also given in this report. The sediment grain size ranged from very fine sand to boulders, with medium sand (diameter $0.25-0.5 \mathrm{~mm}$ ) and coarse sand (diameter $0.5-1.0 \mathrm{~mm}$ ) being dominant. All sediment samples tested in the laboratory had a well-sorted distribution, indicating that the grain sizes were relatively uniform. 
Data availability. Data can be made available by the authors upon request.

Supplement. The supplement related to this article is available online at: https://doi.org/10.5194/nhess-20-933-2020-supplement.

Author contributions. WW and SCH designed the field survey. WW and WCL conducted the field survey in the disaster area. WW and SCH wrote the original draft. SCH managed funding acquisition. WBC corresponded with Taiwanese and Indonesian government offices. PBS and RTI provided early information and mobilized surveyors and measurement tools. All authors contributed to the discussion and interpretation of the results.

Competing interests. The authors declare that they have no conflict of interest.

Acknowledgements. Thanks are due to National Cheng Kung University, Taiwan (especially the Department of Hydraulic and Ocean Engineering), and Universitas Jenderal Soedirman, Indonesia (especially the Department of Civil Engineering and the Institute for Research and Community Service, LPPM Unsoed), which supported fieldwork and laboratory work. We would also like to thank Ujung Kulon National Park and the Tanjung Lesung Special Economic Zone for conducting surveys in their areas. We are grateful to Sumantri from the Tanjung Lesung Special Economic Zone and Budi Prasetyo from Carita Resort for supporting the tsunami impact review and providing detailed chronological information on the tsunami, especially in Tanjung Lesung and Carita Beach, respectively. We appreciate Sanidhya Nika Purnomo for discussion on geographical information.

Financial support. This study was funded by the Ministry of Science and Technology, Taiwan, under grant nos. MOST 108-2221E-006-087-MY3 and MOST 109-2217-E-006-002-MY3.

Review statement. This paper was edited by Ira Didenkulova and reviewed by Ahmet Cevdet Yalciner and one anonymous referee.

\section{References}

Atwater, B. F.: Geologic evidence for earthquakes during the past 2000 years along the Copalis River, southern coastal Washington, J. Geophys. Res.-Solid, 97, 1901-1919, https://doi.org/10.1029/91jb02346, 1992.

BIG - Badan Informasi Geospasial, Indonesia: Seamless Digital Elevation Model (DEM) dan Batimetri Nasional, available at: http://tides.big.go.id/DEMNAS/, last access: 20 January 2020.

BPS - Statistics Indonesia: Statistical yearbook of Indonesia 2019, Jakarta, 2019
BPS - Statistics of Banten Province: Banten Province in figures 2019, Serang, 2019.

BPS - Statistics of Lampung Province: Lampung Province in figures 2019, Bandar Lampung, 2019.

Camus, G., Diament, M., Gloaguen, M., Provost, A., and Vincent, P.: Emplacement of a debris avalanche during the 1883 eruption of Krakatau (Sunda Straits, Indonesia), Geo J., 28, 123-128, https://doi.org/10.1007/BF00177224, 1992.

Dawson, A. G. and Shi, S.: Tsunami deposits, Pure Appl. Geophys., 157, 875-897, 2000.

Dawson, A. G., Hindson, R., Andrade, C., Freitas, C., and Parish, R.: Tsunami sedimentation associated with the Lisbon earthquake of 1 November AD 1755 Boca do Rio, Algarve, Portugal, Holocene, 5, 209-215, 1995.

Dean, R. G. and Dalrymple, R. A.: Coastal processes with engineering application, 1st Edn., Cambridge University Press, Cambridge, 2004.

Dirjen Perhubungan Darat: Perhubungan darat dalam angka 2018 (Land transportation in figures 2018), Jakarta, 2019.

Farreras, S. F.: Post-tsunami field survey procedures: An outline, Nat. Hazards, 21, 207-214, https://doi.org/10.1023/A:1008049228148, 2000.

Fritz, H. M. and Okal, E. A.: Socotra Island, Yemen: Field survey of the 2004 Indian Ocean tsunami, Nat. Hazards, 46, 107-117, https://doi.org/10.1007/s11069-007-9185-3, 2008.

Gelfenbaum, G. and Jaffe, B.: Erosion and sedimentation from the 17 July, 1998 Papua New Guinea tsunami, Pure Appl. Geophys., 160, 1969-1999, https://doi.org/10.1007/s00024-0032416-y, 2003.

Giachetti, T., Paris, R., Kelfoun, K., and Ontowirjo, B.: Tsunami hazard related to a flank collapse of Anak Krakatau Volcano, Sunda Strait, Indonesia, Geol. Soc. Lond. Spec. Publ., 361, 7990, https://doi.org/10.1144/sp361.7, 2012.

Hawkes, A. D., Bird, M., Cowie, S., Grundy-Warr, C., Horton, B. P., Shau-Hwai, A. T., Law, L., Macgregor, C., Nott, J., Ong, J. E., Rigg, J., Robinson, R., Tan-Mullins, M., Sa, T. T., Yasin, Z., and Aik, L. W.: Sediments deposited by the 2004 Indian Ocean Tsunami along the Malaysia-Thailand Peninsula, Mar. Geol., 242, 169-190, https://doi.org/10.1016/j.margeo.2007.02.017, 2007.

Heidarzadeh, M., Ishibe, T., Sandanbata, O., Muhari, A., and Wijanarto, A. B.: Numerical modeling of the subaerial landslide source of the 22 December 2018 Anak Krakatoa volcanic tsunami, Indonesia, Ocean Eng., 195, 106733, https://doi.org/10.1016/j.oceaneng.2019.106733, 2020.

IOC Manuals and Guides No. 37: International Tsunami Survey Team (ITST) Post-tsunami survey field guide, 2nd Edn., edited by: Dominey-Howes, D., Dengler, L., Cunnen, J., and Aarup, T., the United Nations Educational, Scientific and Cultural Organization, Paris, 2014.

Kasbani: Pers Rilis Aktivitas Gunung Anak Krakatau 28 Desember 2018 (Press release Anak Krakatau volcano activity), available at: https://magma.vsi.esdm.go.id/press/view.php? id=173, last access: 22 September 2019.

Maeno, F. and Imamura, F.: Tsunami generation by a rapid entrance of pyroclastic flow into the sea during the 1883 Krakatau eruption, Indonesia, J. Geophys. Res.-Solid, 116, 1-24, https://doi.org/10.1029/2011JB008253, 2011. 
Maramai, A. and Tinti, S.: The 3 June 1994 Java Tsunami: A postevent survey of the coastal effects, Nat. Hazards, 15, 31-49, https://doi.org/10.1023/A:1007957224367, 1997.

Matsutomi, H., Shuto, N., Imamura, F., and Takahashi, T.: Field survey of the 1996 Irian Jaya earthquake tsunami in Biak Island, Nat. Hazards, 24, 199-212, https://doi.org/10.1023/A:1012042222880, 2001.

Moore, A., Nishimura, Y., Gelfenbaum, G., Kamataki, T., and Triyono, R.: Sedimentary deposits of the 26 December 2004 tsunami on the northwest coast of Aceh, Indonesia, Earth Planet. Space, 58, 253-258, 2006.

Morton, R. A., Gelfenbaum, G., and Jaffe, B. E.: Physical criteria for distinguishing sandy tsunami and storm deposits using modern examples, Sediment. Geol., 200, 184-207, https://doi.org/10.1016/j.sedgeo.2007.01.003, 2007.

Muhari, A., Heidarzadeh, M., Susmoro, H., Nugroho, H. D., Kriswati, E., Supartoyo, Wijanarto, A. B., Imamura, F., and Arikawa, T.: The December 2018 Anak Krakatau volcano tsunami as inferred from post-tsunami field surveys and spectral analysis, Pure Appl. Geophys., 176, 5219-5233, https://doi.org/10.1007/s00024-019-02358-2, 2019.

Paris, R., Fournier, J., Poizot, E., Etienne, S., Morin, J., Lavigne, F., and Wassmer, P.: Boulder and fine sediment transport and deposition by the 2004 tsunami in Lhok Nga (western Banda Aceh, Sumatra, Indonesia): A coupled offshore-onshore model, Mar. Geol., 268, 43-54, https://doi.org/10.1016/j.margeo.2009.10.011, 2010.

Paris, R., Wassmer, P., Lavigne, F., Belousov, A., Belousova, M., Iskandarsyah, Y., Benbakkar, M., Ontowirjo, B., and Mazzoni, N.: Coupling eruption and tsunami records: The Krakatau 1883 case study, Indonesia, Bull. Volcanol., 76, 1-23, https://doi.org/10.1007/s00445-014-0814-x, 2014.

Peters, R., Jaffe, B., and Gelfenbaum, G.: Distribution and sedimentary characteristics of tsunami deposits along the Cascadia margin of western North America, Sediment. Geol., 200, 372-386, https://doi.org/10.1016/j.sedgeo.2007.01.015, 2007.

Prabowo, M. R.: Siklon Tropis "Kenanga" Tumbuh di Samudra Hindia Selatan Sumatera (Tropical cyclone to grow in south Sumatra-Indian Ocean), available at: https://www.bmkg.go.id/berita/?p=siklon-tropis-kenangatumbuh-di-samudera-hindia-selatan-sumatera, last access: 15 September 2019.
Richmond, B. M., Buckley, M., Gelfenbaum, G., Morton, R. A., Watt, S., and Jaffe, B. E.: Recent storm and tsunami coarse-clast deposit characteristics, southeast Hawai'i, Mar. Geol., 283, 7989, https://doi.org/10.1016/j.margeo.2010.08.001, 2010.

Setiawan, R., Gerber, B. D., Rahmat, U. M., Daryan, D., Firdaus, A. Y., Haryono, M., Khairani, K. O., Kurniawan, Y., Long, B., Lyet, A., Muhiban, M., Mahmud, R., Muhtarom, A., Purastuti, E., Ramono, W. S., Subrata, D., and Sunarto, S.: Preventing global extinction of the Javan Rhino: Tsunami risk and future conservation direction, Conserv. Lett., 11, 1-9, https://doi.org/10.1111/conl.12366, 2018.

Soeriaatmadja, W.: Indonesia plans traffic system for busy Sunda Strait, available at: https://www.straitstimes.com/asia/se-asia/ indonesia-plans-traffic-system-for-busy-sunda-strait, last access: 10 September 2019.

Soulsby, R. L., Smith, D. E., and Ruffman, A.: Reconstructing Tsunami Run-up from Sedimentary Characteristics - a Simple Mathematical Model, in: Sixth International Symposium on Coastal Sediment Processes - Coastal Sediments'07, vol. 2, Coasts, Oceans, Ports and River Institute (COPRI) of the American Society of Civil Engineers, 13-17 May 2007, New Orleans, 1075-1088, 2007.

Srinivasalu, S., Thangadurai, N., Switzer, A. D., Ram Mohan, V., and Ayyamperumal, T.: Erosion and sedimentation in Kalpakkam (N Tamil Nadu, India) from the 26th December 2004 tsunami, Mar. Geol., 240, 65-75, https://doi.org/10.1016/j.margeo.2007.02.003, 2007.

Srisutam, C. and Wagner, J. F.: Tsunami sediment characteristics at the Thai Andaman Coast, Pure Appl. Geophys., 167, 215-232, https://doi.org/10.1007/s00024-009-0015-2, 2010.

Van Den Bergh, G. D., Boer, W., De Haas, H., Van Weering, T. C. E., and Van Wijhe, R.: Shallow marine tsunami deposits in Teluk Banten (NW Java, Indonesia), generated by the 1883 Krakatau eruption, Mar. Geol., 197, 13-34, https://doi.org/10.1016/S00253227(03)00088-4, 2003.

Verbeek, R. D. M.: The Krakatoa eruption, Nature, 30, 10-15, 1884.

Widiyanto, W., Santoso, P. B., Hsiao, S.-C., and Imananta, R. T.: Post-event field survey of 28 September 2018 Sulawesi earthquake and tsunami, Nat. Hazards Earth Syst. Sci., 19, 27812794, https://doi.org/10.5194/nhess-19-2781-2019, 2019.

Yokoyama, I.: A scenario of the 1883 Krakatau tsunami, J. Volcanol. Geoth. Res., 34, 123-132, https://doi.org/10.1016/03770273(87)90097-7, 1987. 